\title{
Whimperatives across English, Armenian and Russian Cultures
}

\author{
Lusine Madoyan \\ Yerevan State University
}

$\mathrm{T}$ he main aim of the present paper is the study of "whimperatives" and their illocutionary forces in modern English and across different cultures. We want to show that different cultures find expression in different systems of speech acts, and that different types of speech acts become entrenched, and, to some extent, codified in different languages. An attempt will also be made to give a brief outline of different whimperative constructions in modern English discourse, and the way they are translated and used in other languages.

Whimperatives are commands or requests phrased as polite or indirect questions (also wh- imperative). As defined by R. McDermott, a "whimperative" is a command stated in a question form, such as, "Why don't you close the door?" (Mcdermott 1977:25)

English interrogative subjunctives are restricted to requests with only four backshifted modals:

1. (a) Would you mail this for me? $\quad$ (c) Might he be there by now?

$\begin{array}{ll}\text { (b) Could you do me a favour? } & \text { (d) Should I write to him? }\end{array}$

(Dr.Keith Allan 1994:77)

These interrogativeutterances are notably tentative, which accounts for their use in polite contexts.In modern English there are a great number of whimperative constructions, the most frequently used of which are of the following types:

Will you...? , Would you...? , Can you...? , Could you...? Can't you...? etc.

Whimperative constructions have been extensively and meticulously studied by A. Wierzbicka who gives the following main ideas as an outline of a new direction in the study of linguistic interaction:

(i) In different societies, and different communities, people speak differently.

(ii) These differences in ways of speaking are profound and systematic.

(iii) These differences reflect different cultural values, or at least different hierarchies of values.

(iv) Different ways of speaking, different communicative styles can be explained and made sense of, in terms of independently established cultural values and cultural priorities (Wierzbicka 1991:69).

Wierzbicka also states that the ways of speaking are by no means clear in terms of values such as "directness" "indirectness", "solidarity", "spontaneity", "sincerity", "social harmony", "cordiality", "self-assertion", "intimacy" and "self-expression". Since they do not have the same meaning in all cultures, they are used with quite different and even mutually incompatible meanings, and can create confusion, moreover, some languages do not even have corresponding words for all these terms, e.g. there is no word for "self-assertion" in Japanese, Italian, French, Polish or Russian (cf. 1991). Hence, a strong methodological case is made for the use of universally reliant semantic constructs 
that can be translated in all languages, such as "say", "think", "want", "know", "good","bad", "people", "someone", "something", "this", "no". Goddard and Wierzbicka (1994) reason that this universal metalanguage is useful both for a semantic analysis and for a formulation of cultural scripts that "can capture culture-specific attitudes, assumptions and norms in precise and culture-independent terms". For example, Wierzbicka (1991) contrasts the attitude of Anglo-American and Japanese cultures to "self-assertion" and conceives the following underlying conceptual structures:

\begin{tabular}{|l|l|}
\hline Japanese culture & don't say: "I want this", "I don't want this" \\
Anglo-American & do say: "I want this", "I don't want this" \\
Japanese culture & don't say: "I would/wouldn't like (want) this" \\
Anglo-American & do say: "I would/wouldn't like (want) this" \\
Japanese culture & don't say: "I think this/I don't think this" \\
Anglo-American culture & do say: "I think this/I don't think this" \\
\hline
\end{tabular}

The attitude of reserve or restraint, which represents a key value in Japanese culture, cannot be applied to Anglo-American culture, just as the notion of "self-assertion" has no corresponding value in the other culture.

Thus, the analysis comes to prove that Japanese speakers are discouraged from saying clearly what they want, whereas Anglo-American speakers are encouraged to do so. On top of this, Japanese culture places a taboo on asking other people directly what they want. A similar contrast between Japanese and Anglo-American culture exists with regard to the clear and unequivocal expression of personal opinions (Wierzbicka 1991:74).

A. Wierzbicka uses the different interactional norms to account for the differences in linguistic structures characteristically engaged in the two cultures. Thus self-assertion is generally encouraged in Anglo-American culture as long as this does not threaten personal autonomy, i.e. negative face. Thus, one is allowed to say "I want this", but not "I want you to do this".

In their contrastive description of case studies of discourse, Wierzbicka (1991) and Goddard and Wierzbicka (1997) construct cultural scripts of discourse preferences in Japanese, Chinese, Hebrew, Polish, Italian, as well as Black English and White English, Japanese, Polish and Malay. We can conclude that while an Anglo-American may appear direct or blunt to a Japanese interlocutor, the former may label an Israeli as blunt and direct. This preoccupation with the avoidance of such relative and vaguely defined terms as "direct", "blunt", etc. in the contrastive characterisation of speech patterns across cultures provides us with a more valid general picture of differences in speech habits.

This fact explains the ubiquity of the so-called whimperatives- "interrogative directives" -in English, (e.g. Would you do X?, Will you do?, Could you do X?, Can you do $X$ ?, Why don't you do X?, combining the two components in recognition of the addressee's right to freedom from imposition) which is a culture-specific norm for avoiding face-threatening acts. W. K. Hünig states that even if A. Wierzbicka's formulations seem simplistic or naive at first sight, it has to be acknowledged that she offers a method 
of speaking about differences and analyzing them in a non-circular and culture-free "language". This is a major step forward in the vast area of cross-cultural semantics and pragmatics (Hünig 1998). What A. Wierzbicka does not provide is a framework that takes into account a more global perspective and recognizes that different cultures practice different ways of speaking. Such a wider framework is provided by Dell Hymes, who describes speech acts in a global model of communication, i.e. in the context of their material and psychological setting such as the communicative purpose of the communication, the key how to interpret the acts, the instrumental means available, the norms of interaction and the genres (Hymes 2004).

The use of the so-called whimperatives, extremely common in English culture, is almost unheard of in other European languages (Wierzbicka, Gruyter 2003). A request like "Would you mind opening the window" (perhaps watered down even further with a side-order of "it's a bit cold in here") would, if you attempted to render it into a language like Polish, sound quite bizarre - at best it would come across as an inquiry as to whether the addressee is capable of opening the window, but certainly not as a request.

As B. Comrie points out, Russian does not use the Will you or Can you patterns in the way English does, and the same applies to the Would you pattern:

".... in English one polite way of getting someone to do something is by asking a yes/no question using either some form of "will" or some form of "can". In other languages, that's not conventionalized. If you tried it in Russian, the reaction would be "What's this guy trying to do?" (Comrie 1984:282)

Thus, we may say that people speak differently in different societies and communities not only because they speak different languages, but also because they use language differently. These differences reflect different cultural values, or at least different hierarchies of values. This often leads to a communication failure among individuals and social groups. By studying different cultural traditions manifesting themselves in different ways of speaking, we can improve our ability to communicate with others more effectively and to interact with others more fruitfully.

There exist a number of differences between English and other languages in the area of speech acts, which are linked with different cultural norms and cultural assumptions. The results of our research show that English, as different from Armenian and Russian, places heavy restrictions on the use of direct speech acts (especially, direct orders, etc.), and makes an intensive use of indirect speech acts, i.e. whimperatives and other constructions. Features of English are shown to be language specific and due to specific cultural norms and cultural traditions. Linguistic differences are shown to be associated with cultural values such as individualism and respect for personal autonomy in the case of English, and cordiality and collectivism in the case of Armenian and Russian.

The heavy restrictions on the use of the imperative in English and the wide range of interrogative forms in performing acts other than questions constitute striking linguistic reflexes of the Anglo-Saxon socio-cultural attitude. In English the imperative is mostly used in commands and in orders. Other kinds of directives (i.e. of speech acts through which the speaker attempts to cause the addressee to do something) tend to avoid the imperative or to combine it with an interrogative and/or a conditional form. 
In Armenian the use of interrogative forms outside the domain of questions is very limited, and since the interrogative form is not culturally valued as a means of performing directives, there has been, so to speak, no cultural need to develop special interrogative devices for performing speech acts other than questions, and in particular, for performing directives.

Thus, we may say that specific differences between languages in the area of indirect speech acts are motivated, to a considerable degree, by differences in cultural norms and cultural assumptions.

To understand the linguistic and cultural differences mentioned above, we have analyzed some examples of whimperative constructions in English and their translations into Armenian and Russian taken from fiction. First we shall study whimperativeswhich are framed like questions but have the illocutionary force of:

suggestion

“Wouldn't you like to be a star?”(p. 29)

- Bы хотите стать звездой?

- Кто же не хочет? (стр. 220)

- Mıqn id lip uuun qundiul:

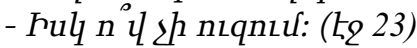

Here we deal with a suggestion and the answer of the hearer confirms this interpretation, because once again it makes clear that the speaker did not expect a yes/no response but rather wanted an action to be done (here, an agreement to be signed).

"What d'you say to a battle of pop to celebrate?" he said. (p. 42)

- Как вы смотрите, не открыть ли нам бутылочку шампанского, чтобы отметить это событие? - спросил он. (стр. 234)

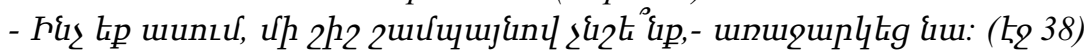

It is worth mentioning that the word "said" in this example is translated into Russian as "asked" which is typical for questions (as the syntactic form of the English variant is that of a question), while the Armenian translator uses the word "suggest" which indicates the illocutionary force of the given utterance.

"Why the hell don't you get a charwoman in?" (p. 46)

- Почему вы не пригласите поденщичу, чтобы она здесь убрала? (стр. 238)

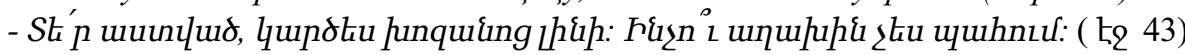

This example is quite interesting because the translators of both languages have considered it necessary to supplement their translations with additional information. If we look at the Russian translation, we can see that it gives a word for word translation, and provides us with some explanation "so as she could clean up the mass". Similarly, in the Armenian variant we come across the following additional information "Oh my God, it's like a pigsty", which is not given in the original variant. Besides, in this example the more common whimperative construction why don't you is replaced with a stronger and more idiomatic variant why the hell don't you, which makes the utterance sound more like reproach or rebuke than suggestion.

"Your cigarette's gone out. Won't you have another?" (p. 154) 
- Ваша сигарета погасла. Возьмите другую. (стр. 349)

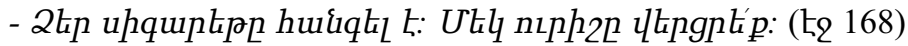

Here the Russian and Armenian variants sound as direct suggestions or even orders, whereas the same semantic component is expressed in English with the help of the indirect question, i.e. whimperative construction won't you do $x$.

"Well, why don't you go and have a look-see?" (p. 156)

- Что ж, пойди и посмотри. (стр. 352)

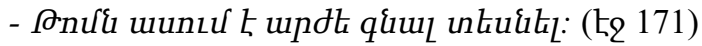

In this example the Russian translation gives a straightforward (bold-on-record) suggestion while the Armenian translation would sound as: Tom says it's worth seeing, so here again the semantic component I suggest you go and see it is present.

"Why don't you talk it over with someone more of your own age?"(p. 211)

- Почему бы тебе не обсудить все эти вещи с кем-нибудь из ровесников? (стр. 408)

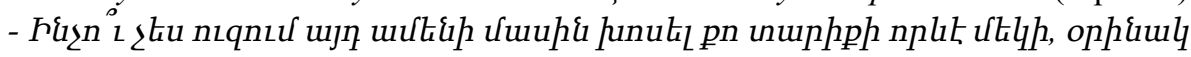
Ponuh htun: (k2 235)

In this example the translator of the Armenian variant introduces the word "want" into the sentence, thus adding some additional overtones and shades of meanings to the utterance, which unfold the following semantic components: the hearer does not want to do $\mathrm{X}$, the speaker reproaches him for that and suggests doing X.

"D'you want me to say good night to you in the passage? I'll just come in for a minute?" (p. 53)

- Ты хочешь, чтобы я пожелал тебе доброй ночи в коридоре? Может, я зайду к тебе на минуту? (стр. 245)

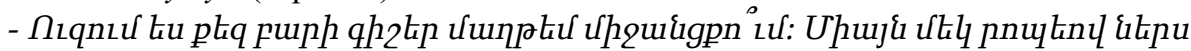
quinituर,- uuuug UujpцL: (to 51)

The Russian variant of this example clearly expresses the illocutionary force of suggestion with the help of the word "maybe" (Может), whereas the Armenian translation sounds closer to the original English variant.

\section{invitation}

"I suppose you wouldn't come to tea with me one day, would you?" (p. 82)

- Вы, наверное, не захотите выпить со мной чамечку чаю как-нибудь на днях? (стр. 276)

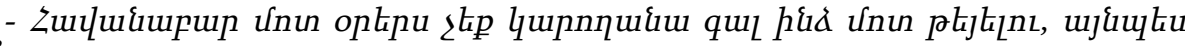
$2 t^{\circ}:\left(k_{2} 86\right)$

In this example the Armenian and the English variants are both tag-questions in their form, whereas the Russian is not. We would also like to draw your attention on the fact that in the Russian translation the part "you wouldn't come to tea" is translated as "you wouldn't like to drink tea" and in Armenian as "you couldn't come to me for tea". In our opinion the illocutionary force indicators are made more apparent and obvious by the Armenian and Russian translators.

“Julia says, will you come and dine on Sunday?” (p. 167)

- Джулия спрашивает, не придешь ли ты к нам пообедать в воскресенье. (стр. 363)

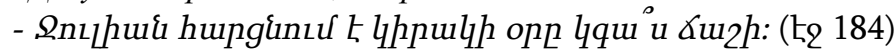


In this example we deal with an invitation dressed up as a question. The English word "says" is translated into both languages as "asks". In choosing a particular verb (request, ask, suggest, or whatever) the reporter imposes a certain interpretation on the original utterance, and can choose one of a number of interpretations compatible with the force signaled by Will you do $x$. In doing so, the reporter adds to what is encoded in the construction itself. This is, then, where the "interminacy" lies: in the range of possible interpretations, which can be signaled by a range of reporting verbs. But the force of Will you do $\mathrm{x}$ is quite determinate.

request, permission

"Can I come in, mummy?” (p. 146)

- Можно войти, мамочка? (стр. 340)

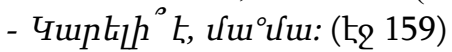

This is a classic example of a whimperative, i.e. a request (asking for permission) dressed up as a question.

"Can you grudge me the happiness it gives me to get you out of a hole?"(p. 104)

- Неужели тебе трудно доставить мне удовольствия и позволить вызволить тебя из беды? (стр. 298)

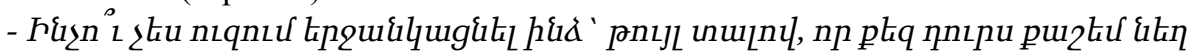

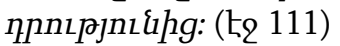

If we translate the Armenian variant back into English, it is more likely to sound as "why don't you grudge me...", so we may conclude that in cases like this the two whimperative constructions can you and why don't you might be interchangeable.

order, reproach

"Why the devil don't you answer when I speak to you?" (p. 124)

- Черт подери, ты почему не отвечаешь, когда я с тобой говорю? (стр. 319)

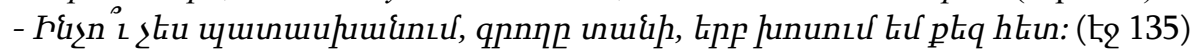

In this example we have an indirect speech act (reproach) with the implied meaning of order (answer, when I speak to you!),and again the insertion Why the devil makes the utterance stronger.

"How can you say a thing like that? The fool.The blasted fool." (p. 143)

(<Как ты можешь так сказать? Дурак. Несчастный дурак!>) (стр. 338)

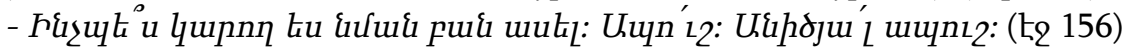

The implied meaning is - do not say such a thing! It is worth mentioning that this example is taken from the heroine's monologue, and the addressee does not hear the speaker. Nevertheless, since the utterance is intended to have some imposition on the "hearer", it can be regarded as a whimperative.

Below we present a table which displays clearly how many times the whimperative constructions of English have been translated into Russian and Armenian in the same way, and how many times the translators have proposed a translation which is different from the original construction.

\begin{tabular}{|l|l|l|l|l|}
\hline \multirow{2}{*}{$\begin{array}{l}\text { Whimperative constructions } \\
\text { translated from English }\end{array}$} & \multicolumn{3}{|l|}{ Into Armenian } & \multicolumn{2}{l|}{ Into Russian } \\
\cline { 2 - 5 } & same & different & same & different \\
\hline 80 & 24 & 16 & 21 & 19 \\
\hline
\end{tabular}


We would also like to draw your attention on the fact that tag questions which are so common in English are very rarely used in Russian. Thus we may conclude that the Armenian and English variants coincide more often.

In conclusion, we would like to state that when translating works of verbal art many translators try to stick to the original expressions. In doing so they use many clichés, expressions and constructions in the translations which are not so typical of the target language. This is done in order to retain the literary style of the author and the work itself.

This is one of the reasons why the results of our research show more coincidence between the original (English) and the translated variants (Russian and Armenian) than there actually is. Thus we might come to a misleading assumption that whimperatives are equally common for the three languages, whereas investigations of speech practice used in everyday communication show that on the conversational level the English use much more indirect speech acts, especially whimperatives than Russians or Armenians do.

Thus, the analysis of different types of whimperative constructions and their use in different cultures enables us to show the close connection between the study of language structure (grammar) and the study of language use (pragmatics).

\section{References:}

1. Brown, P. and Levinson, S.C. (1987) Politeness: Some Universals in Language Usage. Cambridge: CUP.

2. Levinson, S.C. (1983) Pragmatics. Cambridge: CUP.

3. Searle, J.R. (1975) A Taxonomy of Illocutionary Acts. // Language, Mind, and Knowledge. / Ed. by K. Günderson. Vol. 7. Minneapolis: University of Minnesota Press.

4. Searle, J.R. (1975) Indirect Speech Acts. / Ed. by Cole and Morgan. Syntax and Semantics. Reprinted in Searle (1979). New York: Academic Press.

5. Searle, J. (1969) Speech Acts. Cambridge: CUP.

6. Wierzbicka, A. (1985) Different Cultures, Different Languages, Different Speech Acts: Polish vs. English. // Journal of Pragmatics. N 9.

7. Wierzbicka, A. (1991), (2001) Cross-Cultural Pragmatics: The Semantics of Human Interaction. Berlin: Mouton de Gruyter.

\section{Sources of Data:}

1. Maugham, W.S. (1980) Theatre. New York: Collier \& Son.

2. Maugham, W.S. (1985) Tatron. / Tr. from English into Armenian by J. Hovhannisyan. Yerevan: Sovetakan grogh.

3. Maugham, W.S. (1983) Teatr. / Tr. from English into Russian by N. Man, G. Ostrovskaya. M.: Pravda. 


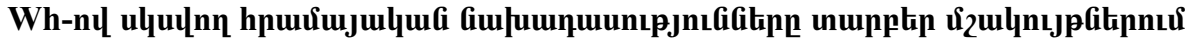

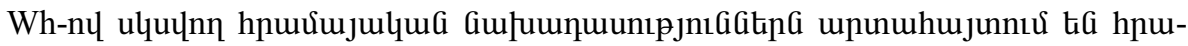

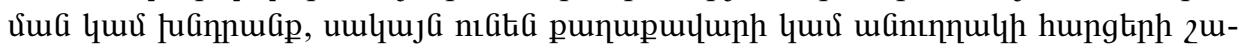
puhjnıumluug unuGåauhuunlnıpjnıGGitinn:

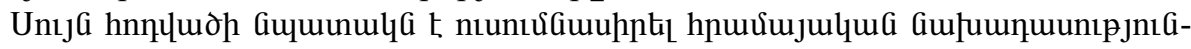

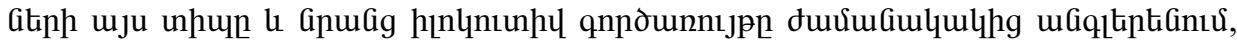

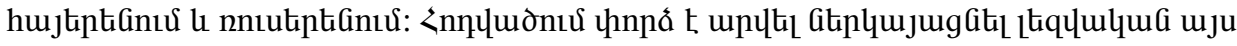

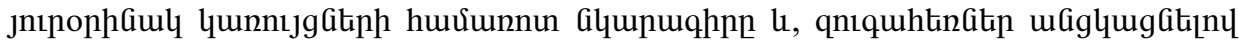

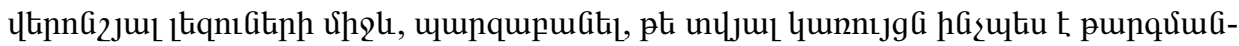

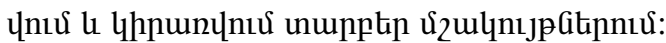

